\title{
Pola makan, obesitas, dan frekuensi serangan pada pasien artritis gout
}

Diet, obesity, and frequency of flares in gout arthritis patients

Fatimah Az-zahra ${ }^{1}$, Dedy Nurwahid ${ }^{2}$, Retno Pangastuti ${ }^{3}$

\begin{abstract}
Background: Trend of gout arthritis prevalence is increasing every year. Obesity, high purine diet, especially from animal source, are some risk factors for recurrent gout attacks. Objective: To evaluate the relationship between diet, obesity and frequency of gout flares in gout arthritis patients. Method: This study was a cross-sectional study with patients from RSUP Dr. Sardjito, RSUD Wirosaban, RSUD Panembahan Senopati that ever diagnosed as gout arthritis within February 2010 - February 2012 which can be seen in the medical record and live in Special District of Yogyakarta with full address provided, as the respondents of this study. Home visit was done for dietary assessment, waist circumference measurement, and interviewing the respondent about gout flares frequency during the last year. Results: Vitamin C consumption in the 1st and 2nd tertiles increase the odds to have any gout flare $(O R=5.5 ; 95 \%$ CI: $1.08-27.77$ and $O R=1.5 ; 95 \%$ CI: 0.29-7.35, respectively). Obesity tend to increase the odds of having any gout flares up to 1.4 times (95\% CI: 0,38-5,25). Conclusion: Low consumption of vitamin C is significantly increase the odds of having any gout flares. The odds is also higher in patients with obesity, though this relationship is statistically insignificant.
\end{abstract}

KEY WORDS: diet, obesity, gout flare

\begin{abstract}
ABSTRAK
Latar belakang: Tren prevalensi artritis gout terus meningkat setiap tahunnya. Salah satu faktor risiko terjadinya serangan berulang adalah obesitas, diet tinggi purin terutama sumber hewani. Tujuan: Mengkaji hubungan antara pola makan, obesitas, dan frekuensi serangan pada pasien artritis gout. Metode: Penelitian cross sectional dengan subjek pasien di RSUP Dr. Sardjito, RSUD Wirosaban Kota Yogyakarta, dan RSUD Panembahan Senopati yang berkunjung antara bulan Februari 2010 s/d Februari 2012, terdiagnosis gout dilihat dari data rekam medis pasien, dan bertempat tinggal di Daerah Istimewa Yogyakarta serta tersedia alamat lengkapnya. Kunjungan ke rumah dilakukan untuk menggali data pola makan, mengukur lingkar pinggang, serta wawancara mengenai frekuensi serangan gout yang dialami selama setahun terakhir. Hasil: Subjek dengan asupan vitamin C pada tertil 1 dan 2 memiliki kemungkinan yang lebih tinggi untuk mengalami serangan ulang gout $(\mathrm{OR}=5,5 ; \mathrm{CI} 95 \%: 1,08-27,77$ dan OR=1,5; CI 95\%:0,29-7,35 secara berturut-turut) sedangkan obesitas cenderung meningkatkan kemungkinan terjadinya serangan gout hingga 1,4 kali (CI 95\%:0,38-5,25). Simpulan: Semakin rendah asupan vitamin C, semakin tinggi kemungkinan terjadinya serangan ulang gout. Kemungkinan terjadinya serangan juga cenderung meningkat pada pasien dengan obesitas, walaupun hubungan tersebut tidak signifikan.
\end{abstract}

KATA KUNCI: pola makan, obesitas, gout, frekuensi serangan

\section{PENDAHULUAN}

Serangan gout akut dicirikan dengan rasa sakit yang menyiksa dan seringkali berulang. Pada satu studi, serangan berulang terjadi pada $62 \%$ pasien dalam 1 tahun dan $78 \%$ dalam 2 tahun, serta $84 \%$

${ }^{1}$ Korespondensi:Politeknik Kesehatan Kementerian Kesehatan Malang, Jl. Besar Ijen No.77 C, Malang, e-mail: azzahrafarha@gmail.com

${ }^{2}$ Bagian Penyakit Dalam Rumah Sakit Umum Pusat (RSUP) Dr. Sardjito, Jl. Kesehatan No. 1, Sekip, Yogyakarta 55284

${ }^{3}$ Instalasi Gizi Rumah Sakit Umum Pusat (RSUP) Dr. Sardjito, Jl. Kesehatan No. 1, Sekip, Yogyakarta 55284 pada tahun ke empat (1). Selain dapat meningkatkan biaya pengobatan pasien, serangan gout yang berulang juga dapat menyebabkan kerusakan struktural yang berlanjut pada pembentukan tofi sehingga dapat menimbulkan efek nyeri, kerusakan sendi, sendi kehilangan fungsinya, serta masalah penampilan pada penderita $(2,3)$. Lebih jauh lagi, penelitian yang dilakukan di Amerika Serikat menunjukkan bahwa pasien yang mengalami serangan gout berulang memiliki kualitas hidup yang rendah (4). 
Penelitian sebelumnya di Inggris juga menganalisis hubungan indeks massa tubuh (IMT) dan frekuensi serangan gout yang menyimpulkan bahwa obesitas adalah salah satu komorbid yang umum pada pasien dengan serangan gout berulang (5). Lingkar pinggang (LP) merupakan indikator obesitas lainnya yang telah terbukti lebih dekat kaitannya dengan hiperurisemia dan resistensi insulin (6), tetapi belum pernah diteliti kaitannya dengan frekuensi serangan gout. Obesitas sendiri berkaitan dengan peningkatan kadar asam urat serum, baik melalui peningkatan produksi maupun penurunan ekskresi asam urat oleh ginjal (7). Beberapa penelitian yang telah dilakukan menunjukkan nilai IMT, LP, rasio lingkar pinggang-panggul yang tinggi adalah beberapa indikator yang berkaitan dengan peningkatan kadar asam urat serum $(6,8)$. Akan tetapi, penelitian lainnya yang dilakukan dengan melihat beberapa indikator lain untuk obesitas yaitu lemak viseral, lemak subkutan, menunjukkan bahwa penumpukan lemak viseral yang memiliki hubungan paling erat dengan peningkatan kadar asam urat serum, bahkan jika dibandingkan dengan IMT $(9,10)$.

Faktor lain yang mempengaruhi risiko terjadinya serangan berulang pada penderita artritis gout adalah diet tinggi purin. Hasil penelitian menyimpulkan bahwa asupan purin yang tinggi dapat meningkatkan risiko terjadinya serangan berulang pada pasien gout sampai dengan 5 kali lipat, terutama asupan purin hewani (11). Penelitian lainnya juga menunjukkan bahwa konsumsi alkohol dapat memicu terjadinya serangan ulang gout. Efek tersebut biasanya muncul 24 jam setelah konsumsi alkohol (12) sedangkan faktor diet lainnya seperti asupan minuman tinggi fruktosa yang terbukti dapat meningkatkan risiko terjadinya gout, serta asupan cairan, produk susu, dan suplementasi vitamin $\mathrm{C}$ yang dapat menurunkan risiko gout belum pernah diteliti kaitannya dengan serangan ulang pada gout (13-15). Oleh karena itu, tujuan penelitian ini adalah untuk mengkaji hubungan antara pola makan, obesitas, dan frekuensi serangan pada pasien artritis gout.

\section{BAHAN DAN METODE}

Penelitian ini merupakan penelitian observasional dengan pendekatan cross-sectional. Subjek penelitian adalah pasien gout berdasarkan rekam medis yang berobat ke Rumah Sakit Umum Pusat (RSUP) Dr. Sardjito, Rumah Sakit Umum Daerah (RSUD) Wirosaban Kota Yogyakarta, dan RSUD Panembahan Senopati antara bulan Februari 2010 sampai dengan Februari 2012, bertempat tinggal di Daerah Istimewa Yogyakarta (DIY) serta tersedia alamat lengkapnya. Kriteria eksklusi adalah subjek yang mengonsumsi obat-obatan seperti aspirin dosis rendah $(<2$ $\mathrm{g} /$ hari) atau diuretik secara regular (setiap hari); subjek tidak dapat ditemui saat kunjungan rumah (pasien pindah, telah meninggal, dll); subjek sedang hamil atau dalam kondisi bed rest sehingga tidak dapat dilakukan pengukuran LP. Peneliti kemudian mencatat alamat subjek terpilih dari rekam medis untuk dilakukan kunjungan rumah. Saat kunjungan rumah, dilakukan pengukuran LP dan wawancara untuk memperoleh data pola makan dan frekuensi serangan gout dalam setahun terakhir.

Penelitian ini dilaksanakan selama bulan April sampai dengan Desember 2013 di DIY. Pemilihan lokasi penelitian ini dengan pertimbangan bahwa prevalensi artritis gout meningkat seiring dengan bertambahnya usia sehingga dipilih DIY yang memiliki persentase lansia tertinggi di Indonesia. Berdasarkan rumus besar sampel dengan level signifikansi $(\alpha)$ sebesar 5\%; kekuatan uji (1- $\beta$ ) sebesar $80 \%$; proporsi terjadinya serangan berulang pada pasien dengan asupan purin pada kuintil tertinggi (P1) sebesar 0,62 (11); dan proporsi terjadinya serangan ulang pada pasien dengan asupan purin pada kuintil terendah (P2) yaitu 0,36 sehingga diperoleh besar sampel yang dibutuhkan untuk penelitian ini sebesar 94 sampel. Pemilihan sampel penelitian menggunakan metode non probability sampling dengan jenis sampling kuota.

Variabel independen berupa pola makan dan obesitas dengan LP sebagai indikator. Data pola makan diperoleh dari wawancara dengan semi-quantitative food frequency questionnaire (SQ-FFQ) yang kemudian dihitung berat makanan yang dikonsumsi setiap harinya untuk setiap golongan (makanan tinggi purin sumber hewani, makanan tinggi purin sumber nabati, minuman tinggi fruktosa, cairan, produk susu, alkohol, serta vitamin C) dan disajikan dalam tertil untuk setiap golongan (g/hari atau $\mathrm{ml} /$ hari) (16). Sementara itu, pengukuran LP dilakukan untuk menentukan kondisi obesitas, dengan kriteria LP lebih dari $80 \mathrm{~cm}$ pada wanita dan lebih dari $90 \mathrm{~cm}$ pada pria (17). Pengukuran 
LP menggunakan pita pengukur dengan ketelitian $0,1 \mathrm{~cm}$. Sebagai variabel dependen, data frekuensi serangan (berupa nyeri, bengkak, dan hangat pada sendi) diperoleh dengan wawancara (self-reported) yang kemudian dikelompokkan menjadi 0 atau tidak ada serangan dan lebih dari atau sama dengan 1 serangan dalam setahun (18). Varibel luar yang juga diteliti antara lain usia, jenis kelamin, komorbiditas, serta konsumsi obat-obatan penurun kadar asam urat. Dalam penelitian ini komorbiditas adalah penyakit penyerta gout yang meliputi hipertensi, diabetes mellitus, gagal ginjal, atau dislipidemia. Data mengenai komorbiditas diperoleh dari rekam medis pasien.

Analisis bivariat menggunakan uji Chi-Square dan dilanjutkan dengan analisis multivariat menggunakan uji regresi logistik. Penelitian ini dilaksanakan setelah mendapatkan persetujuan dari Komisi Etik Fakultas Kedokteran Universitas Gadjah Mada dengan nomor $\mathrm{KE} / \mathrm{FK} / 151 / \mathrm{EC}$ dan surat izin penelitian dari RSUP Dr. Sardjito, RSUD Wirosaban Kota Yogyakarta, dan RSUD Panembahan Senopati.

\section{HASIL}

Terdapat 126 data pasien gout yang diperoleh dari pengambilan data sekunder di RSUP Dr. Sardjito, RSUD Wirosaban Kota Yogyakarta, dan RSUD Panembahan
Senopati. Dari 126 pasien yang dikunjungi rumahnya, hanya 60 pasien yang berhasil menjadi subjek penelitian ini (48\%). Sedangkan sisanya sebanyak 66 pasien (52\%) tidak dapat diambil sebagai subjek karena berbagai alasan (Gambar 1).

Tabel 1 menunjukkan bahwa sebanyak 37\% subjek mengalami minimal 1 serangan gout dalam satu tahun, sebagian besar subjek tergolong obesitas (60\%),

Tabel 1. Karakteristik subjek penelitian

\begin{tabular}{ll}
\hline \multicolumn{1}{c}{ Variabel } & n (\%) \\
\hline $\begin{array}{l}\text { Serangan } \\
\geq 1 \text { serangan }\end{array}$ & $22(37)$ \\
Tidak ada serangan & $38(63)$ \\
Obesitas & \\
$\quad$ Ya & $36(60)$ \\
Tidak & $24(40)$ \\
Usia ( tahun) & \\
$\quad \leq 60$ & $29(48)$ \\
$\quad>60$ & $31(52)$ \\
Jenis kelamin & \\
$\quad$ Laki-laki & $46(77)$ \\
$\quad$ Perempuan & $14(23)$ \\
Komorbiditas & \\
$\quad$ Ada & $47(78)$ \\
Tidak ada & $13(22)$ \\
Konsumsi allopurinol & \\
Tidak & $44(74)$ \\
Ya & $16(27)$ \\
\hline
\end{tabular}

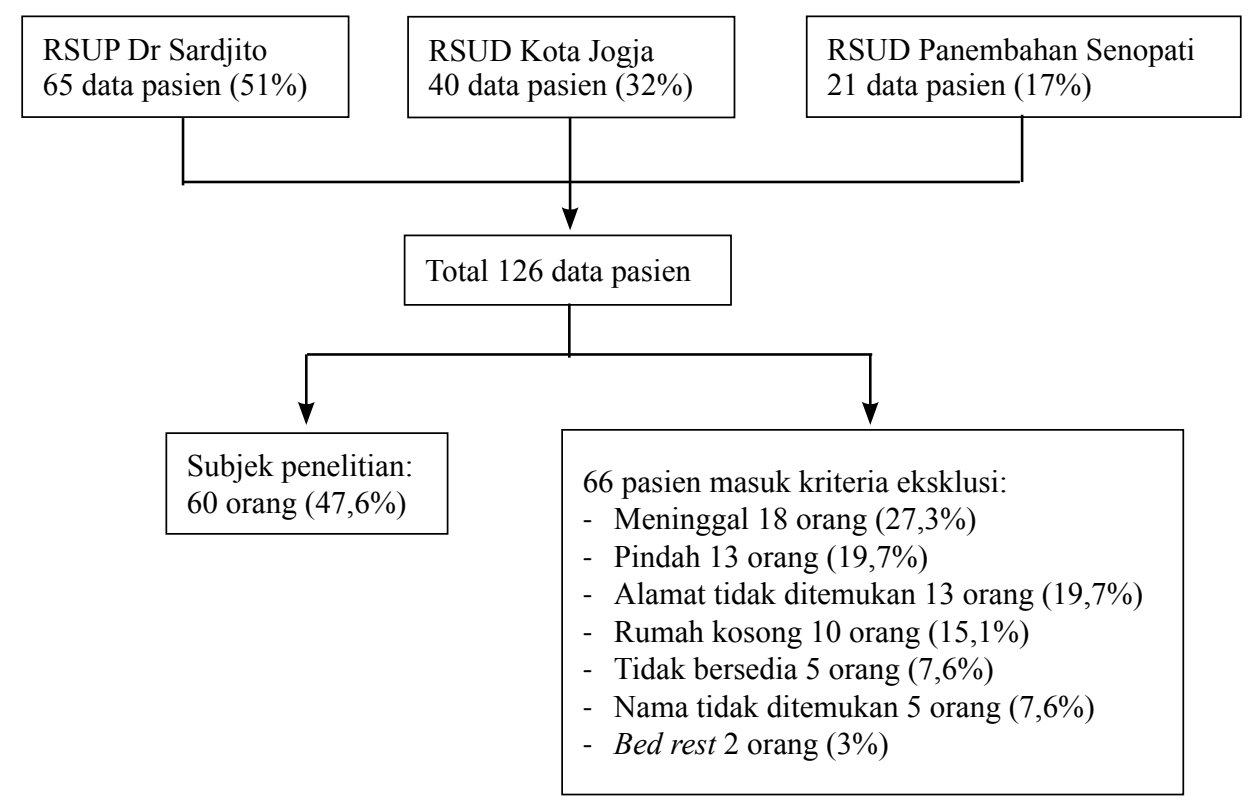

Gambar 1. Proses pengambilan subjek penelitian 
Tabel 2. Hasil Chi-Square pola makan dan frekuensi serangan

\begin{tabular}{|c|c|c|c|c|}
\hline \multirow[b]{2}{*}{ Klasifikasi } & \multicolumn{2}{|c|}{ Serangan $(n, \%)$} & \multirow[b]{2}{*}{$\mathbf{p}$} & \multirow[b]{2}{*}{ OR (CI 95\%) } \\
\hline & $\begin{array}{c}\geq 1 \text { kali } \\
(n=22)\end{array}$ & $\begin{array}{c}\text { Tidak ada } \\
(\mathrm{n}=\mathbf{3 8})\end{array}$ & & \\
\hline \multicolumn{5}{|c|}{ Konsumsi makanan hewani (g) } \\
\hline Tertil $1(\leq 27,6)$ & $8(40)$ & $12(60)$ & \multirow{3}{*}{0,747} & 1 \\
\hline Tertil $2(>27,6-72,8)$ & $8(40)$ & $12(60)$ & & $1(0,28-3,54)$ \\
\hline Tertil $3(>72,8)$ & $6(30)$ & $14(70)$ & & $0,6(0,17-2,38)$ \\
\hline \multicolumn{5}{|l|}{ Konsumsi makanan nabati (g) } \\
\hline Tertil $1(\leq 71,3)$ & $7(35)$ & $13(65)$ & \multirow{3}{*}{0,254} & 1 \\
\hline Tertil $2(>71,3-126,5)$ & $10(50)$ & $10(50)$ & & $1,8(0,52-6,61)$ \\
\hline Tertil $3(>126,5)$ & $5(25)$ & $15(75)$ & & $0,6(0,15-2,42)$ \\
\hline \multicolumn{5}{|l|}{ Konsumsi cairan (ml) } \\
\hline Tertil $1(\leq 1500)$ & $8(40)$ & $12(60)$ & \multirow{3}{*}{0,747} & $1(0,28-3,54)$ \\
\hline Tertil $2(>1500-2000)$ & $6(30)$ & $14(70)$ & & $0,6(0,17-2,38)$ \\
\hline Tertil $3(>2000)$ & $8(40)$ & $12(60)$ & & 1 \\
\hline \multicolumn{5}{|l|}{ Konsumsi produk susu (g) } \\
\hline Tertil $1(0)$ & $8(40)$ & $12(60)$ & \multirow{3}{*}{0,747} & $1,6(0,42-5,76)$ \\
\hline Tertil $2(>0-49,2)$ & $8(40)$ & $12(60)$ & & $1,6(0,42-5,76)$ \\
\hline Tertil $3(>49,2)$ & $6(30)$ & $14(70)$ & & 1 \\
\hline \multicolumn{5}{|c|}{ Konsumsi minuman tinggi fruktosa $(\mathrm{ml})$} \\
\hline Tertil $1(0)$ & $10(50)$ & $10(50)$ & \multirow{3}{*}{0,322} & 1 \\
\hline Tertil $2(>0-17,8)$ & $6(30)$ & $14(70)$ & & $0,4(0,11-1,57)$ \\
\hline Tertil $3(>17,8)$ & $6(30)$ & $14(70)$ & & $0,4(0,11-1,57)$ \\
\hline \multicolumn{5}{|l|}{ Konsumsi vitamin C (mg) } \\
\hline Tertil $1(\leq 19,9)$ & $12(60)$ & $8(40)$ & \multirow{3}{*}{$0,024 *$} & $6(1,4-24.6)$ \\
\hline Tertil $2(>19,9-55)$ & $6(30)$ & $14(70)$ & & $1,7(0,4-7,3)$ \\
\hline Tertil $3(>55)$ & $4(20)$ & $16(80)$ & & 1 \\
\hline
\end{tabular}

Keterangan: * bermakna $(\mathrm{p}<0,05)$

lansia (52\%), memiliki komorbiditas (78\%), dan tidak mengkonsumsi allopurinol (74\%) serta jumlah subjek pria 3 kali lipat dibandingkan jumlah subjek wanita.

Hasil uji Chi-Square (Tabel 2) menunjukkan bahwa subjek yang mengkonsumsi makanan tinggi purin dari sumber hewani pada tertil 2 memiliki kemungkinan yang sama dengan subjek pada tertil 1 untuk mengalami serangan ulang gout, sedangkan subjek pada tertil 3 memiliki kemungkinan yang lebih rendah $(\mathrm{OR}=0,6$; CI 95\%:0,17-2,38). Sementara itu, untuk konsumsi makanan tinggi purin dari sumber nabati, kemungkinan untuk mengalami serangan ulang gout adalah 1,8 kali lipat pada subjek pada tertil 2, sebaliknya subjek pada tertil 3 memiliki kemungkinan yang lebih rendah (OR=0,6; CI 95\%:0,15-2,42). Hubungan antara konsumsi makanan tinggi purin, baik dari sumber hewani maupun nabati dan terjadinya serangan ulang gout tersebut secara statistik tidak menunjukkan hubungan yang bermakna $(\mathrm{p}>0,05)$.
Lebih lanjut untuk konsumsi cairan, dengan tertil 3 sebagai reference, dapat dilihat bahwa subjek pada tertil 1 memiliki kemungkinan mengalami serangan ulang gout yang sama dengan tertil 3 sedangkan subjek yang mengkonsumsi cairan pada tertil 2 memiliki kemungkinan yang lebih rendah. Subjek yang mengkonsumsi produk susu pada tertil 1 dan 2 memiliki kemungkinan 1,6 kali lipat untuk mengalami serangan ulang gout dibandingkan subjek pada tertil 3 sedangkan untuk konsumsi minuman tinggi fruktosa, subjek pada tertil 2 dan 3 memiliki kemungkinan yang lebih rendah untuk mengalami serangan (OR=0,4; CI 95\%:0,11-1,57). Hasil uji Chi-Square antara konsumsi cairan, produk susu, dan minuman tinggi fruktosa dengan terjadinya serangan tidak menunjukkan hubungan bermakna. Sebaliknya, konsumsi vitamin $\mathrm{C}$ menunjukkan hubungan bermakna dengan terjadinya serangan $(\mathrm{p}<0,05)$. Semakin rendah konsumsi vitamin $\mathrm{C}$ maka semakin tinggi kemungkinan untuk terjadi serangan gout. Subjek yang mengkonsumsi 
Tabel 3. Hasil uji Chi-Square obesitas dan frekuensi serangan gout

\begin{tabular}{|c|c|c|c|c|}
\hline \multirow[b]{2}{*}{ Obesitas } & \multicolumn{2}{|c|}{ Serangan $(n, \%)$} & \multirow[b]{2}{*}{$\mathbf{p}$} & \multirow{2}{*}{$\begin{array}{c}\text { OR } \\
\text { (CI 95\%) }\end{array}$} \\
\hline & $\begin{array}{c}\geq 1 \text { kali } \\
(n=22)\end{array}$ & $\begin{array}{c}\text { Tidak ada } \\
(\mathrm{n}=\mathbf{3 8})\end{array}$ & & \\
\hline Ya & $14(39)$ & $22(61)$ & 0,662 & 1,3 \\
\hline Tidak & $8(33)$ & $16(67)$ & & $(0,43-3,75)$ \\
\hline
\end{tabular}

Tabel 4. Hasil uji hubungan variabel lain dan frekuensi serangan

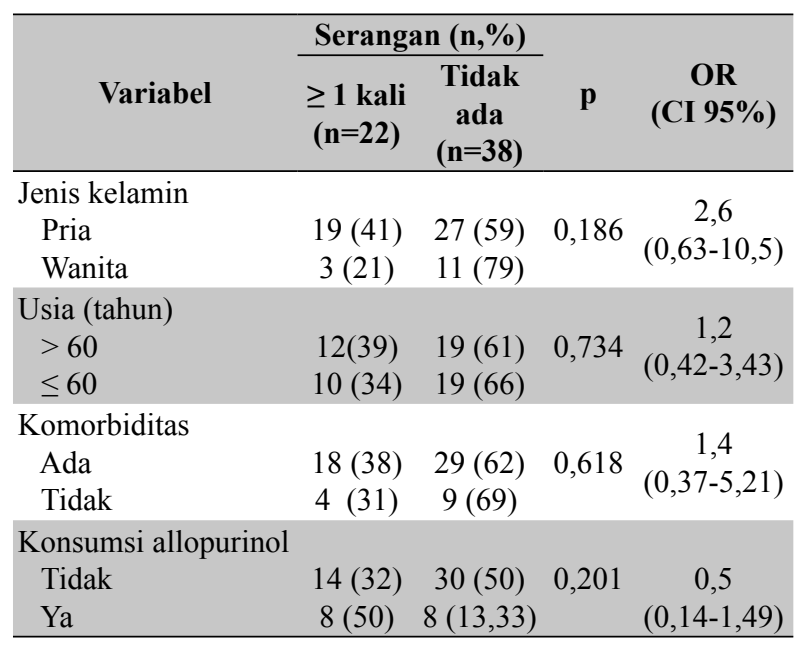

vitamin C pada tertil 2 memiliki kemungkinan 1,7 kali untuk mengalami serangan dibandingkan dengan subjek pada tertil 3, sedangkan subjek pada tertil 1 memiliki kemungkinan yang lebih besar lagi yaitu 6 kali lipat.

Selanjutnya, seperti ditunjukkan pada Tabel 3, setelah dilakukan uji Chi-Square dapat dilihat bahwa subjek yang mengalami obesitas memiliki kemungkinan 1,3 kali untuk mengalami serangan ulang gout walaupun hubungan tersebut tidak bermakna ( $p>0,05)$.

Hasil uji Chi-Square antara variabel luar (jenis kelamin, usia, komorbiditas, dan konsumsi allopurinol) dengan terjadinya serangan juga tidak menunjukkan hubungan yang bermakna secara statistik (Tabel 4). Kemungkinan terjadinya serangan ulang gout lebih tinggi pada subjek pria (2,6 kali), lansia (1,2 kali), dan memiliki komorbiditas (1,4 kali). Sebaliknya, subjek yang tidak mengonsumsi allopurinol kemungkinan yang lebih rendah untuk mengalami serangan ulang gout.

Selanjutnya, dilakukan analisis multivariat dengan uji regresi logistik berganda (Tabel 5). Pada hasil analisis regresi logistik ganda, model 3 menunjukkan bahwa pasien dengan obesitas mempunyai kemungkinan 1,4 kali untuk mengalami serangan ulang gout sedangkan

Tabel 5. Analisis regresi logistik (variabel terikat : frekuensi serangan)

\begin{tabular}{lccc}
\hline \multicolumn{1}{c}{ Variabel } & Model 1 & Model 2 & Model 3 \\
\hline Obesitas & $1,6(0,43-6,25)$ & $1,5(0,41-5,64)$ & $1,4(0,38-5,25)$ \\
Makanan tinggi purin nabati & & & \\
$\quad$ Tertil1 & 1 & 1 & 1 \\
$\quad$ Tertil2 & $1,7(0,36-7,88)$ & $1,6(0,34-7,33)$ & $1,7(0,38-7,81)$ \\
$\quad$ Tertil3 & $0,7(0,13-3,98)$ & $0,7(0,12-3,55)$ & $0,6(0,13-3,38)$ \\
Minuman tinggi fruktosa & & & \\
$\quad$ Tertil1 & 1 & 1 & 1 \\
$\quad$ Tertil2 & $0,5(0,11-2,27)$ & $0,5(0,10-2,10)$ & $0,4(0,09-1,84)$ \\
$\quad$ Tertil3 & $0,9(0,18-5,17)$ & $0,9(0,18-4,98)$ & $0,7(0,15-3,62)$ \\
Produk susu & & & \\
$\quad$ Tertil1 & $1,2(0,23-5,82)$ & $1,4(0,28-6,54)$ & $1,7(0,37-8,11)$ \\
$\quad$ Tertil2 & $0,8(0,16-4,42)$ & $1(0,21-5,05)$ & $1,4(0,32-6,44)$ \\
$\quad$ Tertil3 & 1 & 1 & 1 \\
Vitamin C & & & \\
$\quad$ Tertil1 & $8,3(1,4-47,8)$ & $7,6(1,31-43,67)$ & $5,5(1,08-27,77)$ \\
$\quad$ Tertil2 & 1 & $1,2(0,36-11,5)$ & $1,5(0,29-7,35)$ \\
$\quad$ Tertil3 & $2,4(0,41-13,81)$ & 1 & 1 \\
Jenis kelamin & $2,4(0,46-12,83)$ & & \\
Allopurinol & $0,4(0,09-1,86)$ & $0,4(0,09-1,58)$ & \\
Log Likelihood & $-32,17$ & $-32,76$ & $-33,67$ \\
Pseudo R2 & 0,1841 & 0,1692 & 0,1460 \\
AUROC & 0,7811 & 0,7739 & 0,7656 \\
\hline
\end{tabular}


untuk konsumsi makanan tinggi purin dari sumber nabati, kemungkinan untuk mengalami serangan ulang gout 1,7 kali pada subjek pada tertil 2. Sebaliknya, tertil 3 mempunyai kemungkinan yang lebih rendah untuk mengalami serangan ulang gout $(\mathrm{OR}=0,6$; $\mathrm{CI} 95 \%$ :0,133,38 ). Selanjutnya, dapat dilihat bahwa semakin tinggi konsumsi minuman tinggi fruktosa, semakin rendah kemungkinan untuk mengalami serangan ulang gout $(0,4$ dan 0,7 kali untuk tertil 2 dan 3 secara berturut-turut). Sementara itu, untuk konsumsi produk susu, semakin sedikit asupan produk susu, semakin tinggi kemungkinan terjadinya serangan ulang (1,4 dan 1,7 kali untuk tertil 2 dan 1 secara berturut-turut). Pola yang sama juga terlihat untuk konsumsi vitamin $\mathrm{C}$, yaitu konsumsi pada tertil 2 dapat memiliki kemungkinan terjadinya serangan ulang 1,5 kali dan konsumsi vitamin $\mathrm{C}$ pada tertil 1 memiliki kemungkinan yang lebih besar lagi yaitu 5,5 kali untuk mengalami serangan ulang gout.

\section{BAHASAN}

\section{Hubungan antara pola makan dan frekuensi serangan}

Hasil uji multivariat menunjukkan bahwa konsumsi makanan tinggi purin dari sumber nabati pada tertil ke-2 meningkatkan kemungkinan terjadinya serangan ulang gout sedangkan pada tertil ke-3 menunjukkan hasil yang sebaliknya. Hal ini tidak sejalan dengan hasil penelitian di Amerika Serikat yang menyimpulkan bahwa asupan purin dapat meningkatkan risiko terjadinya serangan ulang gout, walaupun hubungan antara makanan tinggi purin dari sumber nabati tidak memiliki hubungan yang bermakna dengan terjadinya serangan ulang gout (11). Sebaliknya, penelitian lainnya menunjukkan bahwa konsumsi sumber protein nabati pada kuintil tertinggi menurunkan risiko insidensi gout sebanyak $27 \%$, walaupun hubungan tersebut juga tidak bermakna secara statistik (13). Peneliti sebelumnya menyebutkan bahwa hasil yang tidak bermakna tersebut bisa disebabkan oleh adanya zat gizi lainnya yang menyehatkan dalam makanan nabati (seperti serat dan lemak sehat) yang dapat berkontribusi dalam menurunkan peningkatan berat badan dalam jangka panjang dan menurunkan resistensi insulin(11).
Beberapa penelitian telah menunjukkan bahwa minuman tinggi fruktosa dapat meningkatkan risiko hiperurisemia dan gout $(14,19)$. Proses fosforilasi fruktosa meningkatkan kadar adenosin monofosfat (AMP) dan inosin monofosfat (IMP) yang dapat menyebabkan terjadinya peningkatan sintesis asam urat sehingga menyebabkan hiperurisemia (20). Namun, hasil dari penelitian ini sebaliknya yaitu asupan minuman tinggi fruktosa pada tertil 2 dan 3 memiliki kemungkinan yang lebih rendah untuk mengalami serangan ulang gout. Hal ini mungkin disebabkan oleh asupan jus buah yang lebih besar (rata-rata 25,3 $\mathrm{ml}$ ) dibandingkan dengan asupan minuman bersoda (rata-rata 9,8 ml) dalam penelitian ini. Hasil penelitian di Amerika Serikat membuktikan bahwa untuk asupan jus buah, hanya jus jeruk yang menunjukkan hubungan signifikan dalam meningkatkan risiko insidensi gout sedangkan jus buah lainnya maupun asupan buah tidak memiliki hubungan yang signifikan dengan risiko gout (14). Hal ini disebabkan oleh adanya zat gizi lain dalam buah, seperti vitamin $\mathrm{C}$ yang memberikan efek urikosurik dan anti-inflamatori, juga serat yang berkontribusi dalam mencegah peningkatan berat badan dalam jangka panjang dan menurunkan resistensi insulin $(7,9,11)$.

Analisis multivariat menunjukkan bahwa semakin rendah asupan produk susu, semakin tinggi kemungkinan terjadinya serangan ulang gout. Hasil ini sesuai dengan penelitian sebelumnya yang menyimpulkan bahwa produk susu terutama yang rendah lemak, memiliki efek protektif terhadap insidensi gout (13). Efek protektif tersebut disebabkan oleh adanya efek urikosurik dari pencernaan protein susu (kasein dan laktalbumin) sehingga dapat menurunkan kadar serum asam urat serum. Sebaliknya, diit bebas produk susu dalam empat minggu dapat secara signifikan meningkatkan kadar asam urat. Mekanisme urikosurik dari protein susu tersebut masih belum jelas (21).

Lebih lanjut, asupan vitamin $\mathrm{C}$ menunjukkan hubungan yang bermakna dengan terjadinya serangan ulang gout, baik dalam uji bivariat maupun uji multivariat. Semakin rendah asupan vitamin $\mathrm{C}$, semakin tinggi kemungkinan terjadinya serangan ulang gout. Hasil ini sejalan dengan penelitian mengenai hubungan antara vitamin $\mathrm{C}$ dan risiko insidensi gout yang menyimpulkan 
bahwa semakin tinggi asupan vitamin $\mathrm{C}$ semakin rendah risiko gout (15). Efek protektif dari asupan vitamin $\mathrm{C}$ disebabkan oleh adanya efek urikosurik dari vitamin C. Peningkatan kadar vitamin $\mathrm{C}$ pada filtrat dapat menghambat reabsorbsi asam urat secara kompetitif. Potensi lainnya dari mekanisme urikosurik dari vitamin C adalah asupan vitamin $\mathrm{C}$ yang tinggi dapat meningkatkan fungsi ginjal dan laju filtrasi glomerular(22). Selain itu, dijelaskan juga bahwa vitamin $\mathrm{C}$ dapat menghambat aktivasi Nuclear factor-kappaB (NF-k $\beta$ ) karena NF-k $\beta$ akan menstimuli pelepasan interleukin $1 \beta$ yang berperan penting dalam mekanisme inflamasi saat serangan gout (20,23). Hasil penelitian ini juga menunjukkan bahwa konsumsi vitamin $\mathrm{C}$ pada tertil tertinggi masih di bawah angka kecukupan gizi vitamin $\mathrm{C}$ bagi orang dewasa dan lansia yaitu $90 \mathrm{mg}$ untuk pria dan $75 \mathrm{mg}$ untuk wanita (24). Oleh karena itu, pemenuhan asupan vitamin C sesuai dengan kebutuhan setiap harinya dapat menjadi salah satu upaya pencegahan terjadinya serangan ulang gout.

\section{Hubungan antara obesitas dan frekuensi serangan}

Sebanyak $60 \%$ subjek penelitian ini tergolong obesitas. Hasil ini sesuai dengan penelitian sebelumnya yang menyimpulkan bahwa adipositas yang tinggi dan peningkatan berat badan adalah salah satu faktor risiko yang kuat untuk terjadinya gout sedangkan penurunan berat badan memiliki efek protektif(7). Hasil penelitian tersebut menunjukkan bahwa $41 \%$ insidensi gout disebabkan oleh nilai IMT di atas 23 dan insidensi ini terus meningkat seiring dengan meningkatnya nilai IMT.

Berdasarkan hasil analisis multivariat, dapat dilihat bahwa pasien dengan obesitas mempunyai kemungkinan 1,4 kali untuk mengalami serangan ulang gout meskipun hasil tersebut tidak bermakna secara statistik. Hasil penelitian ini sesuai dengan penelitian kohort yang dilakukan di Inggris bahwa risiko terjadinya serangan ulang gout pada pasien gout dengan obesitas adalah 1,2 kali lipat dibandingkan dengan yang tidak mengalami obesitas (5). Parameter obesitas yang digunakan dalam penelitian tersebut adalah body mass index (BMI). Obesitas diduga dapat meningkatkan kadar asam urat serum dengan dua mekanisme yaitu meningkatkan produksi dan menurunkan ekskresi asam urat (7). Dalam penelitian ini, obesitas yang dimaksud adalah obesitas sentral yang diukur dengan indikator LP. Indikator LP memiliki koefisien korelasi yang lebih tinggi terhadap kadar asam urat dibandingkan dengan IMT. Selain memiliki korelasi positif yang lebih tinggi dibandingkan dengan IMT terhadap area lemak viseral, lemak viseral memiliki efek pada metabolisme asam urat yang lebih besar dibandingkan dengan IMT dan lemak subkutan, LP juga lebih tinggi koefisien korelasinya terhadap kadar asam urat serum dibandingkan dengan IMT $(6,10,25,26)$.

Lebih rinci, disimpulkan bahwa akumulasi lemak subkutan berkaitan erat dengan penurunan ekskresi asam urat melalui urin sedangkan penumpukan lemak viseral berkaitan erat dengan peningkatan produksi asam urat(9). Pada pasien dengan penurunan berat badan terlihat bahwa sintesis purin secara de novo menurun sehingga dapat menurunkan kadar asam urat serum (7). Kaitan antara obesitas dan kadar asam urat tersebut menjelaskan hasil penelitian sebelumnya yaitu peningkatan kadar asam urat serum ( $\geq 6 \mathrm{mg} / \mathrm{dl}$ ) berkaitan dengan peningkatan risiko terjadinya serangan ulang gout(27).

\section{SIMPULAN DAN SARAN}

Pola makan yang memiliki hubungan signifikan dengan terjadinya serangan ulang gout adalah asupan vitamin $\mathrm{C}$. Semakin rendah asupan vitamin $\mathrm{C}$, semakin tinggi kemungkinan terjadinya serangan ulang gout. Obesitas berdasarkan parameter LP memiliki kecenderungan untuk meningkatkan kemungkinan terjadinya serangan gout meskipun hubungan tersebut tidak bermakna secara statistik.

Sebaiknya rumah sakit memberikan konsultasi gizi kepada pasien gout untuk mengonsumsi cukup vitamin $\mathrm{C}$ sebagai salah satu upaya pencegahan terjadinya serangan ulang gout. Sebagai contoh, sesuai dengan hasil penelitian ini, buah yang paling banyak dikonsumsi subjek adalah pepaya, pemenuhan kebutuhan vitamin $\mathrm{C}$ salah satunya dapat dicapai dengan mengkonsumsi pepaya potong sebanyak 1 mangkok setiap harinya. Perlu dilakukan penelitian lebih lanjut mengenai pengaruh obesitas dan pola makan terhadap risiko terjadinya serangan ulang gout dengan jumlah sampel lebih besar dan sebaiknya dengan penentuan terjadinya serangan berdasarkan diagnosis dokter. 


\section{RUJUKAN}

1. Underwood M. Diagnosis and management of gout. BMJ 2006;332:1315-9.

2. Rome K, Frecklington M, McNair P, Gow P, Dalbeth N. Foot pain, impairment, and disability in patients with acute gout flares: a prospective observational study. Arthritis Care Res (Hoboken) 2012;64(3):384-8.

3. Wu EQ, Patel PA, Mody RR, Yu AP, Cahill KE, Tang J, Krishnan E. Frequency, risk, and cost of gout-related episodes among the elderly: does serum uric acid level matter? The Journal of Rheumatology 2009;36(5):1032-40.

4. Lee SJ, Hirsch JD, Terkeltaub R, Khanna D, Singh JA, Sarkin A, Kavanaugh A. Perceptions of disease and health-related quality of life among patients with gout. Rheumatology 2009;48(5):582-6.

5. Rothenbacher D, Primatesta P, Ferreira A, Cea-Soriano L, Rodríguez LA. Frequency and risk factors of gout flares in a large population-based cohort of incident gout. Rheumatology (Oxford) 2011;50(5):973-81.

6. Dao HH, Harun-Or-Rashid M, Sakamoto J. Body composition and metabolic syndrome in patients with primary gout in Vietnam. Rheumatology (Oxford) 2010;49(12):2400-7.

7. Choi HK, Atkinson K, Karlson EW, Curhan G. Obesity, weight change, hypertension, diuretic use, and risk of gout in men: the health professionals follow-up study. Arch Intern Med 2005;165(7):742-8.

8. Purnamaratri AW, Subagio HW. Hubungan beberapa indikator obesitas dengan kadar asam urat [Abstrak]. Semarang: Universitas Diponegoro; 2007.

9. Matsuura F, Yamashita S, Nakamura T, Nishida M, Nozaki S, Funahashi T, Matsuzawa Y. Effect of visceral fat accumulation on uric acid metabolism in male obese subjects: visceral fat obesity is linked more closely to overproduction of uric acid than subcutaneous fat obesity. Metabolism 1998;47(8):92933.

10. Takahashi S, Yamamoto T, Tsutsumi Z, Moriwaki Y, Yamakita J, Higashino K. Close correlation between visceral fat accumulation and uric acid metabolism in healthy men. Metabolism 1997;46(10):1162-5.

11. Zhang Y, Chen C, Choi H, Chaisson C, Hunter D, Niu J, Neogi T. Purine-rich foods intake and recurrent gout attacks. Ann Rheum Dis 2012;71:1448-53.

12. Zhang Y, Woods R, Chaisson CE, Neogi T, Niu J, McAlindon TE, Hunter D. Alcohol consumption as a trigger of recurrent gout attacks. Am J Med 2006;119(9):13-8.

13. Choi HK, Atkinson K, Karlson EW, Willett W, Curhan G. Purine-rich foods, dairy and protein intake, and the risk of gout in men. N Engl J Med 2004;350(11):1093-103.
14. Choi HK, Willett W, Curhan G. Fructose-rich beverages and the risk of gout in women. JAMA 2010;304(20):2270-8.

15. Choi HK, Gao X, Curhan G. Vitamin C intake and the risk of gout in men. Arch Intern Med 2009;169(5):502-7.

16. Gibson RS. Principles of nutritional assessment. 2nd edition. New York: Oxford University Press; 2005.

17. Kanazawa M, Yoshiike N, Osaka T, Numba Y, Zimmet P, Inoue S. Criteria and classification of obesity in Japan and Asia-Oceania. World Rev Nutr Diet 2005;94:1-12.

18. Gaffo AL, Schumacher HR, Saag KG, Taylor WJ, Dinnella J, Outman R, Chen L, Dalbeth N, Sivera F, VázquezMellado J, Chou CT, Zeng X, Perez-Ruiz F, Kowalski SC, Goldenstein-Schainberg C, Chen L, Bardin T, Singh JA. Developing a provisional definition of flare in patients with established gout. Arthritis Rheum 2012;64(5):1508-17.

19. Choi JW, Ford ES, Gao X, Choi HK. Sugar-sweetened soft drinks, diet soft drinks, and serum uric acid level: The Third National Health and Nutrition Examination Survey. Arthritis Rheum 2008;59(1):109-16.

20. Pope RM, Tschopp J. The role of interleukin-1 and the inflammasome in gout: implications for therapy. Arthritis Rheum 2007;56(10):3183-8.

21. Choi HK, Mount DB, Reginato AM. Pathogenesis of gout. Ann Intern Med 2005;143(7):499-516.

22. Gao X, Curhan G, Forman JP, Ascherio A, Choi HK. Vitamin $C$ intake and serum uric acid concentration in men. J Rheumatol 2008;35(9):1853-8.

23. Bowie AG, O'Neill LA. Vitamin C inhibits NF-kB activation by TNF via the activation of $\mathrm{p} 38$ mitogen-activated protein kinase. J Immunol 2000;165(12):7180-8.

24. WNPG. Ketahanan pangan dan gizi di era otonomi daerah dan globalisasi. Widyakarya Nasional Pangan dan Gizi X; 2012 November 20-21; Jakarta.

25. Carroll JF, Chiapa AL, Rodriquez M, Phelps DR, Cardarelli KM, Vishwanatha JK, Bae S, Cardarelli R. Visceral fat, waist circumference, and BMI: impact of race/ethnicity. Obesity (Silver Spring) 2008;16(3):600-7.

26. Preis SR, Massaro JM, Robins SJ, Hoffmann U, Vasan RS, Irlbeck T, Meigs JB, Sutherland P, D'Agostino RB Sr, O'Donnell CJ, Fox CS. Abdominal subcutaneous and visceral adipose tissue and insulin resistance in the Framingham heart study. Obesity (Silver Spring) 2010;18(11):2191-8.

27. Shoji A, Yamanaka H, Kamatani N. A retrospective study of the relationship between serum urate level and recurrent attacks of gouty arthritis: evidence for reduction of recurrent gouty arthritis with antihyperuricemic therapy. Arthritis Rheum 2004;51(3):321-5. 